\title{
LATIHAN KONTROL DIRI UNTUK PENURUNAN PERILAKU MEROKOK PADA PEROKOK RINGAN
}

\author{
Irene Hendrika Ramopoly ${ }^{1}$, Kamsih Astuti ${ }^{2}$, Siti Noor Fatmah ${ }^{3}$ \\ ${ }^{12}$ Universitas Mercu Buana Yogyakarta \\ ²tutik.umby@gmail.com
}

\begin{abstract}
Abstrak
Tujuan penelitian ini adalah untuk mengetahui efektivitas latihan kontrol diriuntukpenurunan perilaku merokok pada perokokringan. Desain eksperimen yang digunakan dalam penelitian ini adalah $A B A$, yaitu $\mathrm{A}$ (baseline awal sebelum perlakuan), B (fase intervensi), A (baseline akhir setelah perlakuan ditarik). Subjek dalam penelitian ini adalah 3 orang laki-laki, berusia 20-25 tahun, berdomisili di kota Yogyakarta, dan tergolong perokok ringan.Pemilihan responden dilakukan dengan menggunakan metode screening subjek. Teknik pengumpulan data yang digunakan adalah observasi dan wawancara sebagai pendukungnya. Metode analisis data yang digunakan dalam penelitian ini adalah uji hipotesis Paired Sample T-Test. Dari hasil analisis data dengan Paired Sample T-Test diperoleh nilai $\mathrm{t}=13.035 ; \mathrm{p}<0,01$, sehingga dapat ditarik kesimpulan bahwa terdapat perbedaan signifikan pada perilaku merokok subjek sebelum dan sesudah diberikan latihan kontrol diri, yang artinya perilaku merokok subjek mengalami penurunan sesudah diberikan latihan kontrol diri.
\end{abstract}

Kata Kunci: kontrol diri, perilaku merokok, perokok ringan

\section{SELF CONTROL TRAINING TO DECREASE SMOKING BEHAVIOR IN LIGHT SMOKERS}

\author{
Irene Hendrika Ramopoly ${ }^{1}$, Kamsih Astuti ${ }^{2}$, Siti Noor Fatmah ${ }^{3}$ \\ ${ }^{12}$ Universitas Mercu Buana Yogyakarta \\ ${ }^{2}$ tutik.umby@gmail.com
}

\begin{abstract}
The objective of this research is to determine the effectiveness of self-control training to decrease smoking behavior in light smokers. The experimental design used in this research is ABA, i.e. A (baseline before treatment was given), B (intervention phase), A (final baseline after treatment withdrawn). The subjects of this research were three men, aged 20-25 years old, live in the city of Yogyakarta and classified as light smokers. The selection of respondents was done by using the screening method. The data collection techniques used were observation and interviews as supporting data. The data analysis method used hypothesis Paired Sample T-Test technique. The result of data analysis using Paired Sample T-Test, it was found the value of $t=$ 13.035; $p<0,01$. It can be concluded there is significant differences in the smoking behavior of the subject before and after self-control training, which means that the respondents' smoking behavior decreased after given self-control training.
\end{abstract}

Keywords: self-control, smoking behavior, light smoker

\section{PENDAHULUAN}

WHO memperkirakan terdapat lebih dari 1 milyar perokok di dunia dan lebih dari empat juta kematian berkaitan dengan penggunaan tembakau.Hal yang memperihatinkan adalah kematian yang diakibatkan kebiasaan merokok di Asia telah naik secara drastis dari tahun 1990, sementara negara maju kenaikannya 50\% dari negara-negara Asia. Di Asia Tenggara jumlah perokok selama 30 tahun terakhir menunjukkan 
peningkatan sebesar 1,8\% setiap tahun (Prawitasari, 2012).

Rokok merupakan salah satu zat adiktif, yang bila digunakan dapat mengakibatkan bahaya bagi kesehatan individu dan masyarakat luas. Berdasarkan PP No. 19 tahun 2012 diketahui rokok adalah hasil olahan tembakau yang dibungkus, termasuk cerutu ataupun bentuk lainnya yang dihasilkan dari tanaman Nicotiana Tabacum, Nicotiana Rustica, dan spesies lainnya, atau sintesisnya yang mengandung nikotin dan tar dengan atau tanpa bahan tembakau (Ananda, 2012).

Merokok memberikan resiko tinggi terhadap timbulnya berbagai jenis penyakit serta memberikan resiko kematian. Menurut Wold Health Organization (WHO), sejak 1986 tercatat tiga juta kematian per tahun berkaitan dengan penyakit yang dipicu karena merokok. Selain itu diperkirakan pada 2025 nanti kurang lebih 10 juta kematian akan dipicu oleh rokok, sehingga perlu ada usaha pencegahannya. Berdasarkan pernyataan WHO tersebut, di Indonesia (1996) terdapat 57.000 jiwa atau 157 jiwa meninggal setiap tahun akibat merokok (Sitepoe, 2000). Tidak ada yang memungkiri adanya dampak negatif dari perilaku merokok, tetapi perilakumerokok bagi kehidupan manusia merupakan kegiatan fenomenal artinya meskipun sudah diketahui akibat negatif merokok tetapi jumlah perokok bukan semakin menurun tetapi semakin meningkat dan usia merokok pun semakin bertambah muda (Helmi \& Komalasari, 2000).

Putra, dkk, (2012) menyatakan bahwa perokok aktif dapat dibagi menjadi beberapa kelompok berdasarkan berat dan ringannya derajat merokok. Ramdhani (2013) menyatakan bahwa seorang perokok aktif dapat dikatakan sebagai perokok ringan apabila ia mengisap sekitar 10 batang per hari, perokoksedang (1121 batang per hari) dan perokok berat (21-31 batang per hari).

Dalam penelitian ini, digunakan subjek dengan kategori perokok ringan. Pada awalnya untuk memperoleh informasi mengenai perokok ringan, penulis melakukan wawancara awal terhadap tiga orang subjek, yaitu RE (21 tahun), AJ (22 tahun), CA (22 tahun). Alasan penulis memilih perokok ringan sebagai subjek adalah sebagai tindakan preventif agar perilaku merokok subjek tidak menjadi semakin parah/berat. Hasil wawancara tersebut diketahui, bahwa subjek mulai mencoba untuk merokok sejak SMA dan menjadi perokok aktif setelah memasuki masa awal kuliah. Faktor awal yang menyebabkan subjek merokok, yaitu ajakan teman-temannya ketika berkumpul bersama. Setelah melihat perilaku merokok teman-temannya, subjek memiliki keinginan untuk kembali mencoba merokok dan setelah itu hal ini terus dilakukan terutama ketika subjek sedang mengalami suatu masalah atau ketika berkumpul bersama dengan temantemannya. Pengetahuan mengenai bahaya dan dampak buruk merokok sudah diperoleh subjek dari media sosial, iklan rokok, orang-orang di sekitarnya yang senantiasa mengingatkan subjek akan bahaya merokok (seperti ibunya, ayahnya, saudara-saudaranya yang tidak merokok). Selain itu subjek juga pernah mencoba untuk berhenti merokok namun hal tersebut belum sepenuhnya berhasil dilakukan. Hal yang menyebabkan subjek ingin 
mengurangi jumlah rokok yang dikonsumsi adalah perasaan takut terkena penyakit yang lebih parah dan adanya dorongan dari orangorang terdekatnya untuk berhenti merokok. Ketika subjek mulai berusaha untuk mengurangi merokok dengan upayanya sendiri, subjek mengalami kegagalan. Subjek menyatakan hanya mampu bertahan untuk tidak merokok selama 3 hari hingga satu minggu.Hal yang membuat subjek gagal dalam usaha mengurangi merokok, yaitu subjek tidak mampu menguasai dirinya, tidak mampu menahan dan mengendalikan dorongan/impuls dalam dirinya untuk merokok sehingga subjek mudah terpengaruh oleh ajakan teman-temannya sesama perokok. Dorongan keinginan merokok yang kuat dan sulit dikendalikan muncul ketika subjek mengalami suatu masalah atau ketika berkumpul dengan teman-temannya. Menurut subjek, ketika melihat orang lain merokok maka subjek juga tergerak untuk merokok. Selain itu, merokok merupakan suatu kebiasaan ketika berkumpul bersama dengan teman-temannya, karena jika momen berkumpul bersama dilewati tanpa merokok maka momen tersebut menjadi kurang menyenangkan. Subjek RE mengatakan bahwa jika sedang berpikir, subjek menginginkan untuk merokok agar pikirannya lebih rileks, proses berpikir menjadi lebih mudah dan perasaannya tenang ketika mengalami suatu masalah serta semakin semangat dalam beraktivitas.

Dari alasan-alasan merokok yang dikemukakan di atas, diketahui bahwa perilaku merokok subjek disebabkan oleh pengaruh lingkungan dan aspek psikologis, yaitu efek dan kenikmatan dari rokok. Pemikiran subjek mengenai efek rokok yang menimbulkan kenikmatan menyebabkan subjek sulit untuk menguasai diri dan mengendalikan dorongan yang berasal dari dalam dirinya. Selain itu, merokok bagi subjek adalah suatu kebiasaan pada saat beraktivitas seperti pada saat berkumpul bersama teman-temannya atau ketika mengalami suatu masalah sehingga subjek semakin mudah terpengaruh oleh ajakan teman-temannya meskipun subjek mengetahui dan menyadari berbagai bahaya dan dampak buruk akibat merokok bagi kesehatan tubuhnya. Hal ini sesuai dengan pendapat yang dikemukakan oleh King (2010) yang menyatakan bahwa efek langsung rokok yang menyenangkan sangat sulit untuk diatasi, termasuk oleh orang yang menyadari bahwa merokok adalah "bunuh diri pelan-pelan".

Martin \& Pear (2003) mendefinisikan modifikasi perilaku sebagai sebuah aplikasi sitematis dari prinsip-prinsip dan teknik-teknik belajar untuk mengukur dan meningkatkan tingkah laku individu dalam rangka membantunya agar dapat berfungsi secara penuh di tengah masyarakat. Tingkah laku yang dimaksud meliputi tingkah laku yang nampak (overt) maupun tidak nampak (covert). Tingkah laku yang tidak nampak artinya aktivitas yang terjadi di dalam diri seseorang sehingga membutuhkan instrumen khusus untuk diobservasi oleh orang lain. Salah satu bentuk dari modifikasi perilaku yang dipakai dalam penelitian ini adalah kontrol diri.Menurut Martin \& Pear (2003) kontrol diri adalah usaha yang dilakukan oleh individu untuk mengatur lingkungan sekitarnya dan mengarahkan konsekuensi dari perilakunya sendiri. 
Ramdhani (2013) menyatakan bahwa masalah utama bagi perokok adalah menghentikan kebiasaannya, sekalipun mereka menyadari bahwa rokok berakibat buruk dan dapat mengancam diri mereka. Efek langsung rokok yang menyenangkan sangat sulit untuk diatasi, termasuk oleh orang yang menyadari bahwa merokok adalah "bunuh diri pelanpelan".Pada orang dewasa, perilaku merokok lebih banyak disebabkan karena faktor didalam mereka sendiri, bukan semata-mata pengaruh lingkungan. Niat untuk merokok pada orang dewasa lebih disebabkan oleh faktor dari dalam diri mereka, yang berkaitan dengan kemampuan mengontrol diri. Hal ini sejalan dengan yang dialami subjek, yaitu subjek sulit untuk mengendalikan dan mengontrol dorongan/keinginan yang berasal dari dalam dirinya untuk tidak merokok, meskipun subjek menyadari bahaya dan dampak dari merokok terhadap kesehatan tubuhnya. Hal ini disebabkan karena efek dan kenikmatan dari rokok yang dirasakan oleh subjek yaitu membuat pikiran subjek menjadi lebih ringan, perasaan menjadi lebih tenang dan subjek mampu menyelesaikan masalah yang dialaminya.

Selain itu dengan merokok, momen berkumpul bersama dengan teman-temannya menjadi lebih menyenangkan. Keuntungan dari merokok inilah yang membuat subjek terus mengulang dan melakukan perilaku merokoknya sehingga menjadi suatu kebiasaan. Adanya perhatian atau kesadaran individu mengenai kesehatan mereka yang terancam oleh kebiasaan merokok, memiliki pengaruh yang dapat membantu menghentikan perilaku merokok di kalangan orang dewasa. Kondisi ini menunjukkan bahwa faktor internal (diri) perokok mempunyai pengaruh langsung terhadap perilaku merokok di kalangan orang dewasa. Perubahan perilaku merokok menjadi berhenti merokok akan lebih efektif jika terjadi melalui proses internalisasi, dimana perilaku berhenti merokok tersebut diyakini bernilai positif bagi diri individu sendiri dan diintegrasikan dengan nilai lain dari hidupnya.

Permasalahan inilah yang mendorong penulis untuk memberikan latihan kontrol diri pada subjek dengan tujuan agar subjek mampu menguasai dirinya, mampu menekan impuls/dorongan yang ada dalam dirinya agar tidak mudah terpengaruh dengan godaan yang dapat menimbulkan perilaku impulsif, sehingga hal ini diharapkan dapat berpengaruh terhadap penurunan perilaku merokoknya.

Penerapan teknik kontrol diri terkait dengan perilaku merokok pada perokok ringan sudah pernah dilakukan oleh Ramdhani (2013). Dari hasil penelitiannya diketahui bahwa teknik kontrol diri sangat berperan penting dalam mengendalikan perilaku merokok pada perokok ringan dan teknik kontrol diri berhasil mengurangi konsumsi rokok pada perokok ringan. Selain itu, Ramdhani (2013) juga menyatakan bahwa peserta atau responden dengan kontrol diri rendah cenderung menunjukkan adanya peningkatan penggunaan zat berbahaya, termasuk penggunaan tembakau untuk keperluan merokok begitu juga sebaliknya.

Dalam penelitiannya, Ulhaq \& Kumolohadi (2008) menyatakan bahwa individu yang memiliki kontrol diri yang tinggi, 
akan mampu mengontrol dan mengarahkan perilakunya. Dari hasil penelitiannya mengenai kontrol diri terhadap perilaku merokok, diketahui bahwa individu yang memiliki kontrol diri yang tinggi pada umumnya masih dapat mengontrol dorongan-dorongan dalam dirinya untuk tidak merokok, sedangkan individu yang memiliki kontrol diri rendah, kemungkinannya cenderung tidak mampu melepaskan diri dari dorongan-dorongan untuk merokok. Individu tersebut sangat sulit untuk tidak merokok dan secara terus-menerus terjadi peningkatan jumlah rokok yang diiisap tiap hari, tanpa dapat mempertimbangkan akibat-akibat negatif yang ditimbulkan, baik terhadap dirinya sendiri, ataupun orang-orang di sekitarnya.

Tujuan dari penelitian ini adalah :

1. Memperluas khasanah ilmu psikologi khususnya di bidang profesi psikologi klinis mengenai latihan kontrol diri untuk penurunan perilaku merokok pada perokok ringan.

2. Jika hipotesis ini diterima, maka latihan kontrol diri dapat direkomendasikan sebagai salah satu upaya untuk penurunan perilaku merokok pada perokok ringan.

3. Bagi peneliti lain yang tertarik dengan penelitian serupa dapat digunakan sebagai referensi atau bahan acuan untuk penelitian selanjutnya.

Subjek penelitian ini adalah laki-laki yang memiliki riwayat sebagai perokok ringan dan berdomisili di kota Yogyakarta, dengan kriteria:
1. Mahasiswa dengan rentangusia 20-25 tahun. Menurut Santrock (2012), pada usia 20 tahun yang berakhir pada usia 30-an tahun disebut dengan masa dewasa awal. Pada usia tersebut individu sudah memiliki kemampuan berpikir reflektif sehingga diharapkan dapat memahami proses latihan kontrol diri.

2. Subjek yang digunakan dalam penelitian ini adalah perokok ringan yang mengkonsumsi rokok rata-rata 1-4 batang/hari, dan sudah pernah melakukan usaha untuk berhenti merokok namun gagal. Kategori perokok ringan yang dipakai sesuai dengan yang dikemukakan oleh Smet (1994) \& Aritonang (1997).

Pelaksanaan latihan kontrol diri dilakukan selama 2 hari, yaitu pada tanggal 5 \& 8 Mei 2015 di Laboratorium Fakultas Psikologi Universitas Mercu Buana Yogyakarta.

\section{METODE}

Variabel-variabel yang digunakan dalam penelitian ini dapat diidentifikasi sebagai berikut:

\section{Variabel Bebas: Latihan Kontrol Diri}

Latihan kontrol diri yang dimaksudkan dalam penelitian ini adalah latihan yang mengajarkan dan membantu subjek agar dapat menguasai diri, menekan, menahan dan mengendalikan dorongan/impuls serta mampu melakukan kontrol atas diri sendiri. Hal ini disusun berdasarkan prosedur dari Martin \& Pear (2003), yang meliputi tahapan identifikasi masalah dan penetapan tujuan, pembuatan komitmen untuk pencapaian tujuan dan 
perubahan, analisis data yang sudah dibuat, mendesain program dan mengimplementasikannya kemudian menyusun langkah-langkah pencegahan kekambuhan perilaku yang ingin diubah.

\section{Variabel Tergantung: Perilaku Merokok}

Perilaku merokok adalah kesenangan oral (mulut) dengan memasukkan bahan yang berasal dari dedaunan (tembakau) yang mengandung zat tertentu (khususnya nikotin) dengan cara mengisap dan menghembuskannya sebagai tindakan untuk memperoleh kenikmatan (Ulhaq \& Kumolohadi, 2008). Variabel ini diukur dengan menggunakan behavioral checklistaspek perilaku merokok yang dikemukakan oleh Aritonang (1997), meliputi intensitas merokok, tempat merokok, dan waktu merokok.

Pengumpulan data pada penelitian ini dilakukan dengan menggunakan metode observasi, wawancara dan behavioral checklist perilaku merokok. Wawancara dan observasi ini digunakan untuk memperoleh data yang akandianalisis secara kualitatif. Wawancara dilakukan terhadap subjek di awal dan di akhir penelitian. Wawancara di awal penelitian dilakukan dengan tujuan untuk mengetahui kondisi awal dari perilaku merokok subjek sebelum diberikan perlakuan, sehingga dengan diberikan perlakuan diharapkan dapat berpengaruh terhadap penurunan perilaku merokok subjek. Wawancara di akhir penelitian dilakukan sebagai tindak lanjut (follow-up) untuk mengetahui perkembangan dan kondisi subjek setelah diberikan perlakuan dan sejauhmana subjek dapat menerapkannya dalam kehidupan sehari-hari.
Observasi dilakukan dengan pengamatan terhadap subjek pada saat sebelum perlakuan, selama perlakuan berlangsung, setelah perlakuan dihentikan hingga pada fase followup. Beberapa hal dalam penelitian ini yang diobservasi meliputi: intensitas merokok, waktu merokok dan tempat merokok. Selain dari observasi, data untuk analisis kualitatif juga diperoleh dari lembar kerja yang diberikan pada subjek selama mengikuti latihan kontrol diri.

\section{HASIL DAN PEMBAHASAN}

Hasil analisis visual inspection pada subjek RE,menunjukkan skor perilaku merokok pada pengukuran tahap awal (A1) adalah sebesar 4. Pada fase intervensi (B1) terlihat adanya perubahan grafik jika dibandingkan dengan fase sebelumnya, yaitu sebesar 3,5. Pada fase pengukuran akhir terjadi penurunan sebesar 1,7 dan pada fase follow-up, skor yang diperoleh subjek sama dengan tahap pengukuran akhir (A2), yaitu sebesar 1,7 maka dapat disimpulkan bahwa terdapat penurunan perilaku merokok pada subjek RE selama dan setelah intervensi dilakukan hingga pada fase follow-up.

Hasil analisis visual inspectionpada subjek AJ,menunjukkanskor perilaku merokok pada pengukuran tahap awal (A1) adalah sebesar 4. Pada fase intervensi (B1) terlihat adanya perubahan grafik jika dibandingkan dengan fase sebelumnya, yaitu sebesar 3,5. Pada fase pengukuran akhir terjadi penurunan, yaitu sebesar 1,4 dan pada fase follow-up skor yang diperoleh subjek sama dengan tahap pengukuran akhir (A2) yaitu sebesar 1,4 maka dapat disimpulkan bahwa terdapat penurunan 
perilaku pada subjek AJ selama dan setelah intervensi dilakukan hingga pada fase followup.

Hasil analisis visual inspectionpada subjek CA,menunjukkanskor perilaku merokok pada pengukuran tahap awal (A1) adalah sebesar 3. Pada fase intervensi (B1) terlihat adanya perubahan grafik jika dibandingkan dengan fase sebelumnya, yaitu sebesar 2,5. Pada fase pengukuran akhir kembali terjadi penurunan yaitu, sebesar 0,8 dan pada fase follow-up skor yang diperoleh subjek sama dengan tahap pengukuran akhir (A2) yaitu sebesar 0,8 maka dapat disimpulkan bahwa terdapat penurunan perilaku pada subjek AJ selama dan setelah intervensi diberikan hingga pada fase follow-up.

Dari hasil pengujian hipotesis Paired Sample T-Test, diperoleh nilai $\mathrm{t}=13.035, \mathrm{p}<$ 0,01 , sehingga dapat disimpulkan bahwa terdapat perbedaan yang signifikan pada perilaku merokok subjek sebelum dan sesudah diberikan latihan kontrol diri, yang berarti perilaku merokok subjek mengalami penurunan sesudah diberikan latihan kontrol diri.

Dari hasil analisis kualitatif, menunjukkan terdapat penurunan perilaku merokok pada peserta setelah mengikuti latihan kontrol diri. Selain itu perilaku lain yang menjadi permasalahan peserta selama mengikuti latihan kontrol diri juga mengalami perubahan menjadi lebih baik, yaitu sudah bisa bangun pagi, bisa berhemat, disiplin dan tepat waktu, mengurangi rasa malas dan membuka usaha kecil-kecilan.

\section{KESIMPULAN}

Dari hasil penelitian dapat disimpulkan bahwa secara perhitungan kuantitatif menggunakan uji statitistik Paired Sample TTest, menunjukkan ada perbedaan yang signifikan pada perilaku merokok subjek sebelum dan sesudah diberikan latihan kontrol diri, hal ini dapat dilihat dari nilai $\mathrm{t}=13.035 ; \mathrm{p}$ $<0,01$, sehingga dapat ditarik kesimpulan bahwa terdapat perbedaan yang signifikan pada perilaku merokok subjek sebelum dan sesudah diberikan latihan kontrol diri, yang artinya perilaku merokok subjek mengalami penurunan sesudah diberikan latihan kontrol diri.

\section{SARAN}

Dari hasil penelitian dapat disampaikan beberapa saran sebagi berikut:

1. Bagi subjek penelitian

Diharapkan agar subjek lebih berkomitmen dalam mengikuti latihan hingga selesai, disiplin dan telaten dalam menerapkan serta mempraktikkan langkah-langkah latihan kontrol diri dalam kehidupan sehari-hari sebagai upaya untuk menurunkan perilaku merokok.

2. Bagi peneliti selanjutnya

Diharapkan dapat menyempurnakan penelitian ini dengan memperhatikan hal-hal yang dapat mempengaruhi penelitian. Di dalam penelitian ini, peneliti hanya menggunakan 3 peserta, sehingga disarankan untuk menambah jumlah peserta, waktu intervensi yang digunakan hanya 2 hari, sehingga keterbatasan waktu juga mempengaruhi efek dari perlakuan yang diberikan terhadap subjek, karena subjek kurang dapat menerapkan materi latihan lebih lama. 


\section{DAFTAR PUSTAKA}

Aditama, T. Y. (1997). Rokok dan kesehatan. Edisi ke 3. Jakarta: Gramedia.

Ajzen, I., \& Fishbein, W, (1975). Belief, Attitude, Intention and Behavior: An Introduction to Theory and Research. London: Addition Wesley Publishing.

Ananda, D. (2012). Mengurangi kebiasaan merokok menggunakan pendekatan konseling behavior strategi self control pada siswa SMA Negri 1 Natar tahun ajaran 2012/2013. Diunduh dari https://himcyoo.files.wordpress.com tanggal 15 April 2014.

Ardini, R. F., \& Hendriani, W. (2012). Proses berhenti merokok secara mandiri pada mantan pecandu rokok dalam usia dewasa awal. Jurnal Psikologi Pendidikan dan Perkembangan, 1(2), 17.

Aritonang, (1997). Fenomena wanita merokok. Skripsi (tidak dipublikasikan). Yogyakarta: Fakultas Psikologi Universitas Gajah Mada.

Barlow, D., \& Hersen, M. (1984). Single Case Experimental Design: Strategies for Studying Behavior Change. United States of America.

Baumeister, R.F., Muraven, M., \& Tice D. M. (1998), Self control as limited resource: Regulatory depletion pattern. Journal of Personality and Social Psychology, 16(6), 351-355.

Baumeister, R.F. (2002). Ego depletion and self-control failure: An energy model of the self's executive function. Self and Identity, (1), 129-136.

Baumeister, R.F., Kathleen., \& Tice, D. M. (2007). The strength model self-control. Association for psychologycal science, journal or personality and social psychology, 16 (6), 351-355.

Calhoun, J.F., \& Accocela, R,J., (1995). Psikologi dan hubungan kemanusiaan (terjemahan dari Prof. Dr. Ny R. S Satmoko), Semarang: IKIP Semarang Press.
Cooper, O.J., (1987). Applied behavior analysis. Ohio: Merril Publishing Company.

Chotidjah, S. (2012). "Makara sosial humaniora". Fakultas Ilmu Pendidikan, Universitas Pendidikan Indonesia, Bandung.16 (1).49-56. Diunduh dari www.journal.ui.ac.id/index.phptanggal 24 Agustus 2014.

De-Ridder, D. T. D., \& de-Wit, J. B. F. (2006). Self Regulation in Health Behavior. New Jersey: John Wiley \& Son Ltd.

Fawzani, N \& Triratnawati, A. (2005). "Makara kesehatan": Terapi Berhenti Merokok (Studi Kasus 3 Perokok Berat). Jurusan Antropologi, Fakultas Ilmu Budaya. Universitas Gadjah Mada Yogyakarta, 9(1), 17-22.

Golfried, M.R., \& Merbaum, M. (1973). Behaviour Change Through Self Control. New York: Holt, Rinehart \& Winston.

Jaya, H. (2013). "Realibilitas Inter Rater", Assesmen Pembelajaran. Pendidikan Kejuruan. PPS Universitas Negri Makassar. Diunduh dari http://hanriansyahjaya.files.wordpress.co m,tanggal 20April 2015.

Komalasari, D., \& Helmi, A, F. (2000). FaktorFaktor Penyebab Perilaku Merokok Pada Remaja. Jurnal Psikologi (1). Diunduh dari http://avin.staff.ugm.ac.id, tanggal 15 April 2014.

King, A. L. (2010). Psikologi umum sebuah pandangan apresiatif. Jakarta: Penerbit Salemba Humanika.

Kumolohadi, R.A.R. (2008). "Hubungan Antara Kontrol Diri Dengan Perilaku Merokok Pada Siswa Siswi SMAN 1 Parakan". Naskah publikasi, 3-22. Diunduh dari http:// psychology.uii.ac.id tanggal24 Agustus 2014.

Latipun (2011). Psikologi Eksperimen. Malang: Penerbit UMM Press.

Martin, G., \& Pear, J. (2003).Behaviour Modification: what it is and how to do it. New Jersey: Pearson Pretience Hall. 
Messina, J. (2010). Developing self control.Chapter 15: Developing selfControl Tools for Handling Control Issues. Diunduh dari http://jamesjmessina.com/toolsforcontroli ssues/developselfcontrol.html, tanggal24 Agustus 2014

Mettlin. (1973). Smoking as Behavior: Applying a Social Psychological Theory. Journal of Health and Social Behavior, 14 (2). 144-152. Diunduh dari http://www.jstor.org tanggal 24 Agustus 2014.

Mutadin. (2002). Remaja dan rokok. Diunduh darihttp://www.e-

psikologi.com/artikel/individual/remajarokok tanggal 24 Agustus 2014.

Pami. (2013). Keuntungan dan kerugian rokok. Diunduh dari http://www.pamibengkulu.blogspot.com tanggal 15 April 2014.

Prakoso, K, I. (2013). Pengertian rokok dan bahaya merokok bagi kesehatan manusia. Diunduh dari http://desarancawiru.blogspot.com tanggal 15 April 2014.

Prawitasari, J, E (2011). Psikologi Terapan Melintas Batas Disiplin Ilmu. Jakarta: Erlangga.

Putra, (2012). Hubungan derajat merokok dengan derajat eksaserbasi asma pada pasien asma perokok aktif di bangsal paru RSUP DR. M. Djamil Padang tahun 2007-2010. Diunduh dari http://jurnal.fk.unand.ac.id tanggal 24 Agustus 2014.

Priyatno, D. (2012). Belajar cepat olah data statistik dengan SPSS. Yogyakarta: Penerbit ANDI.

Raharjo, J. (2011). Efek psikologis akibat merokok. Diunduh dari http://www.mediajoko.blogspot.comtangg al 15 April 2014.

Sandek, R \& Astuti, K. (2007). Hubungan Antara Sikap Terhadap Perilaku Merokok dan Kontrol Diri Dengan Intensitas Berhenti Merokok. Insight Jurnal Ilmiah Psikologi.5(1), 1-8.
Santrock, J. W. (2012). Life-Span Development: Perkembangan Masa Hidup Edisi Ketiga Belas Jilid 2. Jakarta: Erlangga.

Sari, P. (2013). Pelatihan dalam psikologi industri dan organisasi. Diunduh dariwww.12013pus.blogspot.com tanggal 24 Agustus 2014.

Satiti, A. (2009). Strategi Rahasia Berhenti Merokok. Cetakan I. Yogyakarta: Data Media.

Sitepoe. (2000). Kekhususan Rokok Indonesia. Jakarta. Gramedia.

Skinner, E. A. (1996). A guide to constructs of control. Journal of Personality and Social Psychology, 71(3), 549-570.

Smet, B. (1994). Psikologi Kesehatan. Jakarta. Grasindo.

Soekadji, S. (1983). Modifikasi Perilaku: Penerapan Sehari-hari dan Penerapan Professional. Jakarta. Liberty.

Syafiie, R, M, "Stop smoking": Studi kualitatif terhadap pengalaman mantan pecandu rokok dalam menghentikan kebiasaan merokoknya. Fakultas Psikologi Universitas Diponegoro, Semarang. 6-21. Diunduh dari http://eprints.undip.ac.id, tanggal 24 Agustus 2014.

Sunberdg, N, D, Winebarger, A, A, Taplin J, R. (2007). Psikologi Klinis: Perkembangan Teori, Praktik dan Penelitian. Edisi keempat. Yogyakarta. Pustaka Pelajar.

Widhiarso, W (2010). "Melibatkan Rater Dalam Pengembangan Alat Ukur". Diunduh dari www.widhiarso.staff.ugm.ac.id tanggal 20 April 2015. 